\title{
WORKSHOP PENGAYAAN MATERI BIDANG TRAVEL BAGI GURU \& SISWA SMK ANCOP DUSUN LIKOTUDEN DESA KAWALELO, FLORES TIMUR
}

\author{
Ina Veronika Ginting ${ }^{1}$ \\ Program Studi Manajemen Bisnis Perjalanan, Sekolah Tinggi Pariwisata Bandung \\ ina_veronika@stp-bandung.ac.id
}

\begin{abstract}
Abstrak
Pendidikan vokasi menjadi perhatian pemerintah dalam upaya meningkatkan sumber daya manusia agar memiliki keterampilan daya saing yang baik. Pendidikan vokasi mendukung ketersediaan sumber daya manusia (SDM) pariwisata di destinasi pariwisata di Indonesia. Pendidikan vokasi SMK Pariwisata juga memberikan pengalaman kerja dan penerapan pengetahuan dan keterampilan bagi siswanya. Dalam pengembangan kapasitas sekolah menghasilkan SDM yang berkualitas, SMK ANCOP Likotuden belum dapat memenuhi tenaga pendidik yang berkualitas hingga sekarang. Kegiatan pengabdian masyarakat ini dilaksanakan selama 10 hari dan melibatkan program Studi Manajemen Bisnis Perjalanan STP Bandung dengan tujuan memberikan pengayaan materi keterampilan terkait dengan bidang Travel dan meningkatan kemampuan intrapersonal dan interpersonal (soft skill) baik pendampingan bagi guru maupun penguatan materi bagi siswa SMK Ancop Likotuden. Metode yang digunakan untuk materi keterampilan melalui praktikum dengan prasarana yang sangat terbatas seperti penggunaan global informasi yaitu Computer Reservation System (CRS), Global Distribution System (GDS),Ticketing Domestik dan Ticketing International. Pengayaan materi ini dilakukan dengan teori maupun praktik, materi soft skill melalui paparan diskusi di dalam kelas maupun di luar sekolah. Hasil dari kegiatan ini berupa kemampuan pemahaman mengajar bagi guru-guru Jurusan Usaha Perjalanan Wisata serta pemahaman bagi siswa SMK di bidang Travel Services sehingga memiliki pengetahuan dan keterampilan, disiplin, kemandirian, serta inisiatif beradaptasi dengan professional pariwisata
\end{abstract}

Kata Kunci : pendidikan vokasi, travel agent, soft skill

\section{PENDAHULUAN}

Peranan pariwisata menjadi sebuah industri yang sangat besar pada saat ini dan terus berkembang ke masa yang akan datang secara terus menerus. Untuk menghadapi perkembangan yang pesat ini maka harus diimbangi dengan pertumbuhan dan perkembangan pengetahuan dan keahlian untuk menghadapi tantangan-tantangan ke depan.

Keberhasilan dalam menghadapi tantangan tersebut memerlukan sumber daya manusia yang siap dan memiliki employability skill atau keterampilan kerja sehingga dapat terserap di industri pariwisata khususnya industri perjalanan dan bahkan menjadi pengusahapengusaha muda dalam industri ini. Untuk dapat menghasilkan sumber daya manusia yang siap pakai maka dunia pendidikan harus terus mampu beradaptasi dan mengikuti perubahan tehnologi yang cepat dan tantangan globalisasi yang cukup tinggi dengan memiliki pengetahuan, keterampilan dan kemampuan dalam menganalisis perkembangan serta beradaptasi dengan perubahan. Untuk menghasilkan sumber daya manusia demikian maka dibutuhkan tenaga pendidik sebagai pengajar vokasi yang juga dapat dengan cepat tanggap pada perubahan teknologi untuk memenuhi kebutuhan industri 
pariwisata dan industri perjalanan baik nasional maupun secara international.

Perubahan ini juga menuntut kebutuhan tenaga pendidik vokasi bidang industri perjalanan yang dapat merancang kurikulum yang disampaikan dengan berbasiskan kompetensi. Kurikulum pariwisata yang berbasis pada kompetensi yang diakui secara internasional dan diharapkan dapat diuji dengan menggunakan standar internasional. Pembelajan dengan standar kompetensi ini diharapkan dapat diaplikasikan dalam proses pembelajaran sehingga lulusan Sekolah Menengah Kejuruan (SMK) vokasi pariwisata yang berkualitas untuk memenuhi kebutuhan sumber daya manusia Indonesia siap bersaing.

Tantangan-tantangan dan tuntutan perubahan pada dunia usaha maupun industri perjalanan sangat membutuhkan lulusan yang mampu langsung bekerja bahkan mampu membuka usaha dalam bidang pariwisata dan perjalanan. Penyediaan pengajar berkompetensi dibidang vokasi merupakan jawaban dalam mempersiapkan lulusan SMK vokasi yang berkualitas dapat menjawab tantangan dalam menghasilkan lulusan yang dibutuhkan pada dunia usaha dan industri perjalanan khususnya.

Data dari Kementerian Tenaga Kerja RI melalui Detik.com (2018) menyatakan bahwa jumlah tenaga kerja terampil dan bersertifikasi adalah sebanyak 1.349 juta. Walaupun demikian, jumlah yang dipersiapkan dan ditargetkan secara nasional pada tahun 2019 adalah sebanyak 1.500 juta. Sebagai contoh, di sektor pariwisata, penambahan jumlah tenaga kerja tersertifikasi ditahun 2018 yang telah dilakukan oleh Kementerian Pariwisata melalui data Bisnis.com adalah berjumlah 400.000 orang. Jumlah tersebut dianggap kurang untuk memenuhi kebutuhan industri sehingga ada target penambahan menjadi sebanyak 500.000 orang di tahun 2019. Dari data tersebut, dapat diilustrasikan bahwa kenyataan dan permintaan kebutuhan tenaga kerja di semua sektor, khususnya sektor pariwisata umumnya dan usaha perjalanan wisata pada khususnya masih menjadi sebuah tantangan dan perlu ditingkatkan terutama di daerah pedalaman (remote area) yang memiliki potensi wisata yang cukup tinggi. Kemampuan penyediaan sumber daya manusia dibidang perjalanan yang berkompetensi sangat dibutuhkan khususnya para pengajar sebagai ujung tombak dalam penyediaan lulusan-lulusan siswa SMK Pariwisata yang siap kerja dan sesuai dengan kebutuhan industri.

Pelatihan yang ditawarkan adalah sinergi antara bidang keilmuan pariwisata khususnya industri perjalanan dengan mengenal ekosistem pariwisata serta peran pendidikan dalam membangun pariwisata di Flores, dan aspek-aspek di bidang industri pariwisata khususnya dalam penanganan tiket penumpang melalui reservasi Global Distribution System (GDS) dan perhitungan tiket normal domestik dan internasional.

Pelatihan ini dirancang untuk memberikan gambaran bagi guru vokasi di bidang pariwisata khususnya Usaha Perjalanan Wisata dengan overview dari kesempatan bisnis dan keterampilan yang dibutuhkan di bidang perjalanan bagi para siswa SMK Pariwisata. Pelatihan ini mencakup pada pemahaman bagi siswa SMK Ancop bahwa travel sebagai distribution network, intermediary, provider dan supplier dalam peran dan sertanya berfungsi sebagai Travel agent dalam sebuah system kepariwisataan. Dengan demikian para siswa SMK Acop yang mengikuti pelatihan bisa mendapatkan pengetahuan, keahlian dan kemampuan berkomunikasi dalam industri perjalanan sehingga dengan pelatihan ini diharapkan dapat meningkatkan kompetensikompetensi penting dalam bidang usaha perjalanan dan dapat memenuhi kebutuhan kompetensi dibidang perjalanan yang dibutuhkan di industri perjalanan, sehingga dapat meningkatkan kompetensi para lulusan SMK Pariwisata sebagai sumber daya manusia pariwisata yang lebih berkualitas di Flores, Nusa Tenggara Timur.

\section{METODE}

Kegiatan pengabdian masyarakat ini dibuat dalam bentuk workshop pelatihan khususnya mata pelajaran Reservasi dan Tiketing Domestik \& International. Workshop 
ini juga memberikan pemahaman potensi wisata pembentuk produk paket wisata di Flores. Pengayaan materi bertujuan bertujuan untuk menghadapi Praktik Kerja Industri (Prakerin) bagi siswa dan siswi kelas XI yang akan dilaksanakan di travel agent maupun airlines yang ada di Jakarta, Bali, Labuhan Bajo, Kupang selama 6 bulan, selain itu juga merupakan persiapan menghadapi ujian akhir (UN) bagi siswa kelas XII serta pengayaan materi bagi guru pengampu mata pelajaran Reservasi dan Tiketing di SMK Ancop. Pembekalan ini dilaksanakan dari tanggal 18 24 November 2019 yaitu selama 7(tujuh) hari.

Pembekalan ini juga merupakan lanjutan pengabadian masyarakat penulis yang pernah dilaksanakan bersama dengan dosen-dosen Pradita Institute Jakarta yang dilakukan kepada sebagian guru-guru dan siswa angkatan sebelumnya yaitu pada tanggal 21 januari s.d 31 januari 2019 yang lalu yang dilaksanakan dengan mendatangkan sebagian siswa yang akan melakukan praktik kerja industri di Jakarta dan guru-guru SMK Ancop ke Universitas Pradita Institute Jakarta. Lanjutan dari pengabdian masyarakat ini yayasan sekolah SMK Ancop mengharapkan penulis dapat secara langsung mendampingi siswa dan guru-guru jurusan Usaha Perjalanan Wisata (UPW) di SMK Ancop desar Likutuden, Larantuka Flores Timur. Hasil komunikasi dengan pengurus Yayasan Ancop bidang kurikulum bersama dengan guru-guru Usaha Perjalanan Wisata maka penulis dapat Menyusun topik pelatihan sesuai dengan kebutuhan SMK Ancop. Dalam pelaksanaan pelatihan ini, penulis menyusun agenda pelatihan yaitu:

Tabel 1 - Susunan Materi Pelatihan

\begin{tabular}{|c|l|}
\hline No & \multicolumn{1}{|c|}{ Materi } \\
\hline 1 & Pelayanan jasa perjalanan \\
\hline 2 & $\begin{array}{l}\text { Motivasi dan Pengenalan Travel } \\
\text { Agent }\end{array}$ \\
\hline 3 & Pengenalan produk wisata Larantuka \\
\hline 4 & $\begin{array}{l}\text { Reservasi dengan menggunakan } \\
\text { Global Distribution System( GDS) }\end{array}$ \\
\hline 5 & Tiketing Domestik \\
\hline 6 & Tiketing Internasional \\
\hline
\end{tabular}

Metode praktikum ini dilaksanakan di ruang kelas dan juga di luar kelas dikarenakan fasilitas yang dimiliki cukup lengkap tetapi agak kesulitan di jaringan internet sehingga penulis dan siswa serta guru harus mencari tempat yang agak jauh dari sekolah untuk dapat mengakses internet sebagai akses utama dalam belajar penggunaan teknologi informasi salah satu Global Distribution Susytem (GDS) yaitu sistem Sabre .

\section{HASIL DAN PEMBAHASAN}

Berikut adalah hasil dan pembahasan dari proses pelaksanaan pengayaan praktik kerja nyata dan persiapan Ujiian Nasional (UN) yang bersifat paparan, diskusi yaitu motivasi dan pengenalan travel agent, pengenalan produk wisata Larantuka, serta praktik reservasi dan Tiketing Domesti dan International .

1. Paparan dan Diskusi

a) Perjalanan jasa perjalanan, topik ini bagaimana cara pelayanan yang baik dalam pariwisata khususnya di bidang perjalanan. Pendalaman terhadap sikap kerja dalam pelayanan di bidang pariwisata sangat perlu. Budaya dan kebiasaan salam atau greeting masyarakat Flores merupakan hal awal yang sudah sangat baik melekat pada siswa, tetapi banyak hal juga yang harus dipahami untuk menampilkan sikap intrapersonal maupun interpersonal sangat dibutuhkan. Penulis melihat bahwa sikap dan kedisiplinan siswa sudah terbentuk, hal ini karena semua siswa diwajibkan untuk tinggal di asrama sekolah dan harus mematuhi peraturan sekolah baik secara individu maupun dengan teman dan guru. Siswa bersama guru bersama-sama diajak memahami sikap dasar dalam pelayanan yang diperlukan oleh tamu atau wisatawan dalam industri perjalanan antara lain:

- mengenali jenis-jenis tamu

- mengenali prosedur kerja perusahaan pada umumnya di travel agent maupun airline

- mengenali berbagai keluhan tamu

Pendidikan 722 
- sikap membantu dan penyelesaian berbagai masalah yang muncul di industry

- sikap kerja disiplin, jujur dan ketekunan kerja

- pentingnya bekerja dengan tim

- pentingnya penguasaan bahasa asing terutama Bahasa Inggris sebagai kemampuan komunikasi

Semua kemampuan dan sikap ini diberikan contoh- contoh dan penanganan yang sering terjadi di industry. Selama pelatihan ini penulis, guru dan siswa membuat kesepakatan dalam praktik dasar atas sikap pelayanan yang baik seperti ketepatan waktu, kerja sama dengan kelompok, greeting, kerja sama tim dalam penyelesaian masalah serta penggunaan Bahasa Inggris pada sesi tertentu selama pelatihan.

b) Motivasi dan pengenalan Travel Agent, para siswa siswi serta guru UPW diberikan pencerahan atau insight mengenai industri pariwisata dan bisnis travel agent. Siswa diberikan gambaran mengenai perananan bisnis travel dalam ekosistem pariwisata, produk jasa yang dijual oleh Travel agent, alur bisnis sederhana travel agent serta principalprinsipal yang bekerja sama dengan travel agent. Hal ini agar siswa dapat memahami mengenai alur bisnis travel yang akan menjadi tempat mereka melakukan Prakerin. Siswa dan siswi juga diberi pembekalan mengenai sejarah lahirnya travel agent, pengertian dari pariwisata dan yang terkait dalam ekosistem pariwisata secara sederhana. Pemahaman perbedaan antara Biro Perjalanan Wisata serta Agent Perjalanan Wisata. Mereka juga diajak untuk mengetahui bagaimana proses bisnis yang dilakukan di travel agent baik antara Biro Perjalanan Wisata dan Agent Perjalanan Wisata maupun Tour Operator, Wholesaler. Selain itu juga agar siswa dan siswi mengetahui produk pelayanan yang dijual di Travel Agent seperti paket wisata, penanganan dokumen perjalana, tiket, transportasi, voucher hotel, MICE, Paket Cruise, dll. Mereka juga diajak memikirkan siapa saja pasar yang bisa menjadi target market dari Travel Agent di daerah mereka sehingga bisa menumbuhkan jiwa wirausaha setelah mereka lulus SMK.

c) Pengenalan produk wisata Larantuka, materi ini merupakan diskusi sederhana yang dilakukan dengan siswa dan siswi SMK Ancop dimana banyak berdomisili di pelosok Kabupaten Flores Timur dan Kabupaten lainnya seperti Maumere dan Lembata yang sangat kaya dengan potensi budaya dan alamnya terkhusus bahari. Setelah selesai pelatihan setiap hari penulis mengajak siswa dan guru sekolah berkeliling desa sekitar sekolah untuk belajar bersama mengenali dan menemukenali potensi wisata yang dapat dijadikan sebagai atraksi wisata di sekitar sekolah. Kegiatan ini mengajak mereka untuk dapat mengenali potensi wisata yang ada didaerah mereka masing-masing. Siswa yang terbagung secara tidak langsung diberi pembekalan secara langsung untuk mengitepretasikan potensi wisata di daerah mereka masingmasing. Setiap sore siswa bergantian memetakan potensi wisata daerah mereka seperti potensi alam seperti pantai sangat indah dengan berbagai keunikan beserta dengan taman laut yang sangat indah, gunung api didalam laut, gunung, sungai serta sampai pada perburuan ikan paus, penangkaran mutiara dengan kualitas internasional yang banyak di ekspor ke Jepang. Selain itu memiliki wisata budaya seperti tenun ikat dan ciri khasnya sesuai daerah mereka, moke (minuman khas), adat istiadat di Larantuka seperti perkawinan, upacara keagamaan, perang tanding, rumah adat masyarakat flores, dan lain sebagainya. Mereka juga memiliki wisata agro seperti wisata tanaman sorgum atau jejawut yang mulai langka sebagai ketahanan pangan dan

Pendidikan 723 
makanan sehari-hari di Larantuka, kacang mete kualitas ekspor, asam jawa, kelor dan pohon cendana yang juga memiliki kualitas ekspor. Siswa juga menceritakan Wisata religi yang selalu didatangi oleh wisatawan ribuan wisatawan mancanegara dan domestik yaitu "Prosesi Samana Santha" yang digelar setiap tahun pada bulan april yaitu perayaan Tri Suci Paskah umat Katolik yang ternyata hanya ada di Indonesia dan Portugal bahkan pada saat ini Portugal sudah jarang melakukannya. Selain Larantuka juga merupakan kota memiliki banyak bangunan heritage seperti gereja tua, bangunan peninggalan Portugis serta peninggalan kerajaan Larantuka. Para siswa banyak yang tidak menyadari potensi produk wisata yang ada disekitar mereka, dengan kegiatan jalan santai ini para siswa dan guru dapat menilai berbagai potensi wisata yang ada dapat dijadikan sebagai produk wisata. Mereka juga belajar mengenali potensi wisatawan yang tertarik pada wisata di Larantuka yang masih sangat kental dengan budaya dan keaslian serta keindahan alamnya. Dengan kegiatan ini mereka menyadari bahwa sesuatu yang mereka anggap merupakan produk yang biasa saja memiliki potensi wisata yang sangat besar dan bisa menjadi produk wisata unggulan yang dibingkai dalam paket wisata dan interpretasi yang menarik dapat dipromosikan dengan memanfaatkan sosial media yang mereka gunakan sehari seperti Facebook, Instagram, Whatsapp, dan lain sebagainya dapat menjadi sarana dalam memperkenalkan daerah mereka. Pengenalan potensi ini juga menumbuhkan kebanggaan pada tanah leluhur mereka untuk tetap dapat dijaga dan dilestarikan dan menyadari daerah mereka sangat memiliki potensi yang cukup besar di bidang pariwisata. Kegiatan belajar sambil bermain ini dirasakan penulis sangat efektif dalam menggali pengetahuan siswa terhadap pengenalan produk wisata lokal, yang juga merupakan salah satu kompetensi yang harus dimiliki oleh siswa SMK pariwisata.

d) Reservasi dengan menggunakan Global Distribution System (GDS), pada pelatihan ini penulis memberikan praktik penggunaan Sistem Sabre sebagai salah satu sistem GDS yang banyak digunakan di travel di Indonesia yang menghubungkan teknologi antara travel agent dengan Airlines international secara live atau online. Hanya saja sistem ini diperlukan aplikasi yang harus di install pada perangkat komputer dengan kapasitas tertentu serta dibutuhkan jaringan internet yang cukup kuat, hanya saja dikarenakan SMK Ancop cukup jauh dari kota walaupun memiliki fasilitas komputer cukup tetapi jaringan internet tidak baik membuat pelatihan ini agak terhambat. Solusi yang dapat dilakukan adalah melakukan pelatihan Sistem Reservasi Sabre ini di tepi pantai penangkaran mutiara yang dimiliki seorang warga Jepang. Pantai yang cukup jauh dari sekolah ini memiliki jaringan internet cukup baik. Pelaksanaan pelatihan yang kami sebut "sekolah alam" dengan menggunakan fasilitas seadanya yaitu di gudang penyimpanan mesin yang dimiliki pengusaha mutiara dengan menggunakan genset sebagai listrik. Dengan segala kekurangan di "sekolah alam" di tepi pantai, penulis akhirnya dapat memberikan pelatihan Sabre secara interaktif dan menyenangkan kepada 25 orang siswa dan 2 orang guru jurusan UPW selama 4 (empat) hari dengan menggunakan jaringan internet melalui telepon seluler, 1 (satu) komputer yang telah di install dengan Sistem Sabre, bantuan infokus serta layar seadanya. Pada pelaksanaannya siswa-siswi dan guru pendamping diberi pembekalan praktik pembuatan Pasanger Name Record (PNR ) melalui Sistem Sabre yaitu: Sign in/out, Host reference system, 
decode and encode, schedule display, air availability, displaying direct access availability, Flight information, Simple Booking atau Passenger Name Record (PNR) yang terdiri dari Phone field, Receive from, Itinerary, Name, Ticketing $\&$ end of transaction, Cancel segment dan Change Status, penyimpanan dan perubahan data pada PNR, General Fact Field, Pre-reserve seat, Frequent Travel Numbers, Email Address, Divide PNR (Split PNR). Pelaksanaan pelatihan Sabre ini dilakukan di luar sekolah selama 4 hari, seluruh mahasiswa dengan cara membentuk kelopok kerja. Siswa dibimbing dan dilatih secara bergantian bagaimana cara membuat reservasi dan perubahan-perubahan reservasi atau modify booking. Siswa dan guru diajak untuk memahami terminologi airlines aturan-aturan, International Airlines Transportation Assosiation (IATA) sebagai dasar dalam reservasi tiket international. Seluruh siswa serta guru pendamping sangat senang dan merasa tertarik menggunakan Sistem Sabre, karena mereka dapat melakukan reservasi penerbangan internasional dengan live booking sehingga kompetensi melakukan reservasi didapatkan di pelatihan ini.

e) Tiketing Domestik, pada pelatihan setelah melakukan pelatihan reservasi diajak bagaimana menghitung harga tiket pesawat domestic. Pelatihan ini menggunakan langsung website airlines domestik atau melalui Sistem online travel agent (OTA) yang menggunakan system penjualan tiket yaitu Business to Consumer (B2C) seperti Traveloka, Ticket.com dan juga menggunakan salah satu sistem penjualan tiket domestik dengan sistem Business to Business (B2B) yang banyak digunakan oleh travel agent di Indonesia yaitu salah satunya sistem Voltras. Dengan menggunakan sistem Voltras, siswa dan juga guru pendamping bisa membuat reservasi sendiri, melakukan perhitungan tiket domestik dan dapat langsung mengetahui jumlah komisi yang akan didapat dari penjualan tiket sebagai sub agent ataupun agent dari Voltras. Kegiatan ini juga memberikan pemahaman langsung dalam alur bisnis penjualan tiket di travel agent. Siswa dan guru untuk memiliki semangat menjadi entrepreneur dalam penjualan tiket domestic mengingat bahwa pergerakan masyarakat NTT sangat tinggi menggunakan pesawat domestic yang terdiri dari kepulauan-kepulauan kecil dengan bandara yang ada di hampir semua kabupaten. Dengan melihat sistem ini dan peluang pasar yang ada serta pemanfaatan tehnologi digital, mereka merasa bahwa mereka juga dapat menjadi sub agent dalam menjual tiket pesawat domestic maupun international.

f) Tiketing Internasional, pada pelatihan ini diberikan bagi siswa kelas XII dalam persiapan menghadap Ujian Nasional (UN) serta pendalaman bagi guru pengampu Tiketing Internasional. Pemahaman Ticketing Internasional yang diberikan di ruangan kelas dengan menggunakan fasilitas official airline guide (OAG), Air Tariff Around the World yang dimiliki oleh jurusan UPW. Pelaksanaan dilakukan setiap hari dari pukul 19.00 - 20.30 WITA selama penulis berada di SMK Ancop sebagai persiapan dalam menghadapi Ujian Nasional untuk matapelajaran Dokumen Pasasi Internasional. Para siswa kelas XII merasa sangat terbantu untuk lebih memahami perhitungan tiket internasional secara manual dengan mengikuti aturan atau rules dari IATA. Dalam pembekalan ini yang dipelajari adalah penguatan city code dan airport code international, pembagian dunia berdasarkan IATA area \& sub IATA area atau disebut juga Traffic Conference (TC), dari pembagian IATA area ini maka mereka memahami mengenai jalur penerbangan melalui Global Indicator (GI) yang menjadi dasar dalam perhitungan tiket internasional

Pendidikan 725 
dengan menggunakan Mileage System. Pada perhitungan Mileage System secara manual ini siswa serta guru diberi pemahaman dalam menggunakan OAG dan air tariff untuk mendapatkan dan memahami Neutral Unit Currancy (NUC), Maximum Permited Mileage (MPM), Ticketed Permitted Mileage (TPM), Higher Intermediate Fare (HIF), Extra Mileage Allowance (EMA), Extra Mileage Surcharge (EMS), dan lainnya yang digunakan. Mileage system ini merupakan formula dalam mengitung harga tiket internasional secara manual dengan menggunakan beberapa contoh perhitungan dengan rute atau itinerary international. Perhitunngan tiket internasional yang tadinya dirasakan sulit dan rumit, sekarang lebih mudah dipahami dan dilakukan setelah semua aspek dan terminologi bener-berner dipahami oleh siswa. Pada pendalaman Ticketing Internasional ini guru pengampu juga mendapatkan pemahaman yang lebih lagi dalam bagaimana mengajar perhitungan tiket internasional dengan menggunakan IATA rules dan bagaimana pemanfaatan buku Air Tarrif dan OAG dalam mendapatkan elemen perhitungan tiket sesuai dengan kebutuhan kurikulum untuk mata pelajaran Dokumen Pasasi Internasional.

g) Sebagai kelanjutan, pendampingan tetap dilakukan oleh penulis kepada guru-guru pengajar UPW tidak hanya pada saat di Larantuka tetapi pendampingan masih tetap dilakukan sampai saat ini. Pendampingan yang dilakukan antara lain memberi pendampingan bagi guru dalam penyelesaian soal-soal tiket internasional yang tidak dimengerti untuk latihan bagi siswa dengan online. Penulis juga mendamping pengurus Yayasan SMK Ancop bidang kurikulum dan guru UPW dalam pembuatan modul, dan bahan mengajar beberapa mata pelajaran sesuai dengan capaian pembelajaran sesuai dengan Standar Kualifikasi Kerja
Nasional Indonesia (SKKNI). Modul, bahan ajar yang sedang disusun adalah mata pelajaran Food \& Service di kelas XI \& XII, Kepemanduan dan MICE. Penyusunan modul ini, penulis banyak dibantu beberapa praktisi hotel, guide dan MICE yang sudah berpengalaman dibidangnya.

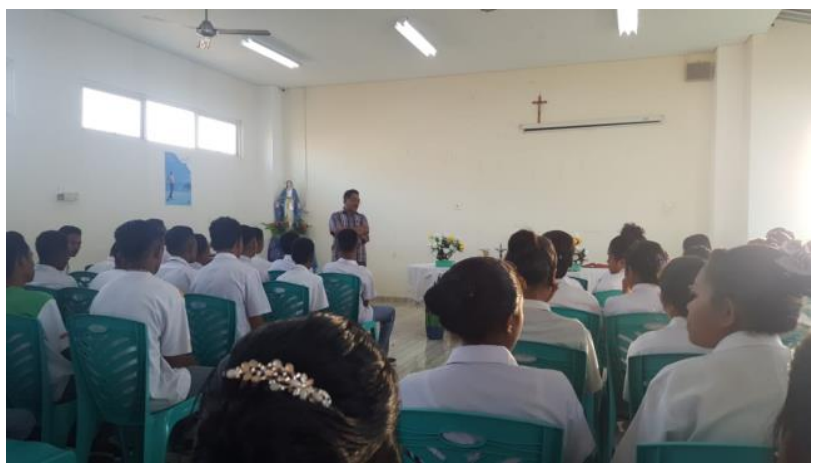

Gambar 1 - Perkenalan kepada seluruh siswa SMK oleh kepala Sekolah SMK Ancop

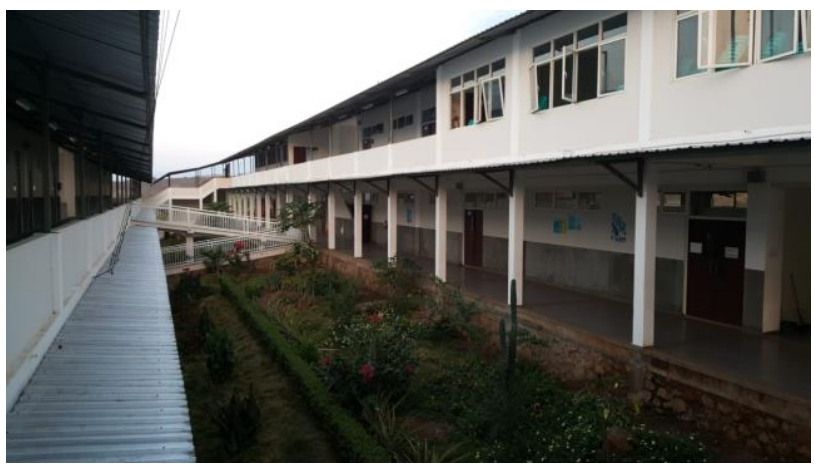

Gambar 2 - Sekolah SMK Ancop, desa Likutuden , Flores Timur 

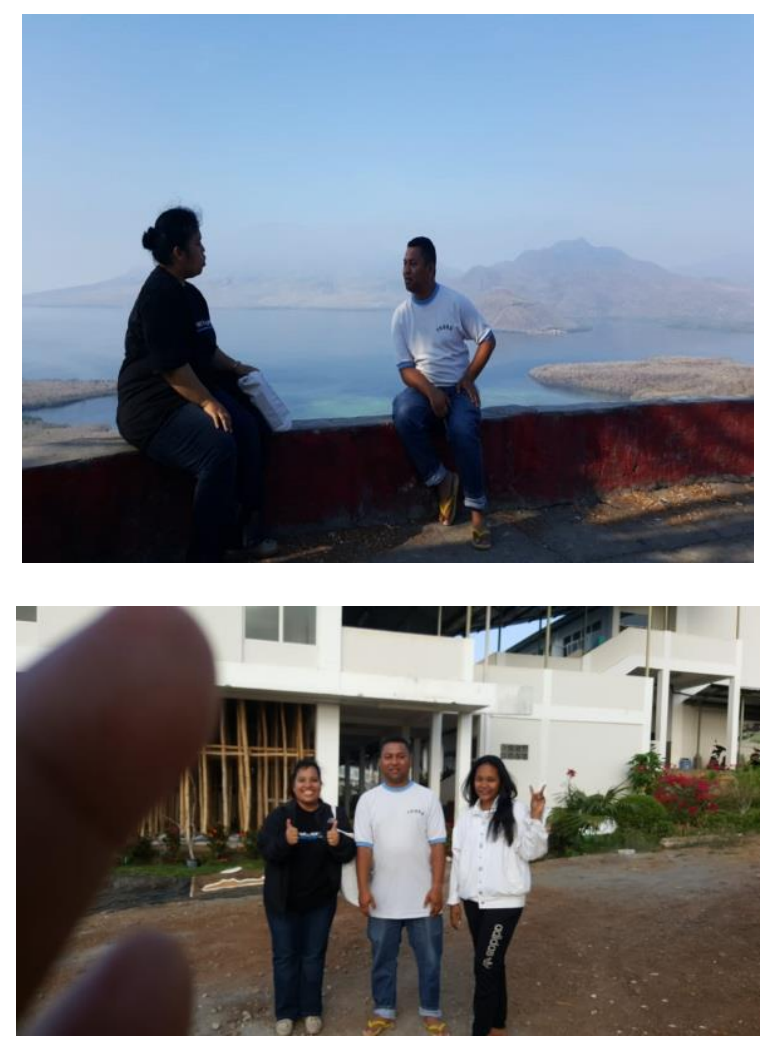

Gambar 3 - Bersama 2 orang guru vokasi Jurusan UPW

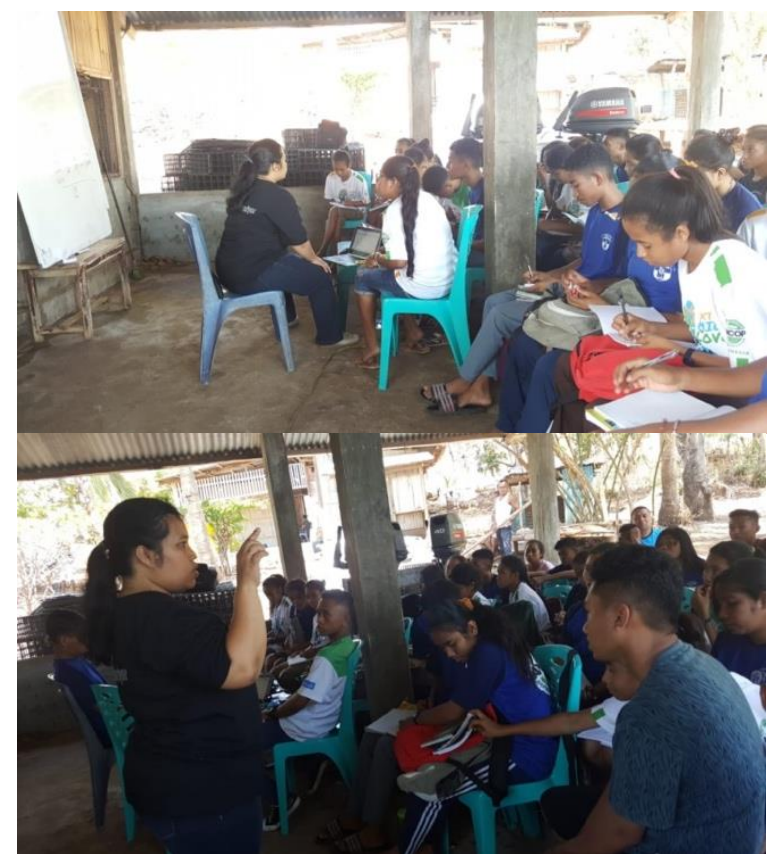

Gambar 4 - Suasana pelatihan Sabre di tepi pantai untuk mendapatkan jaringan internet

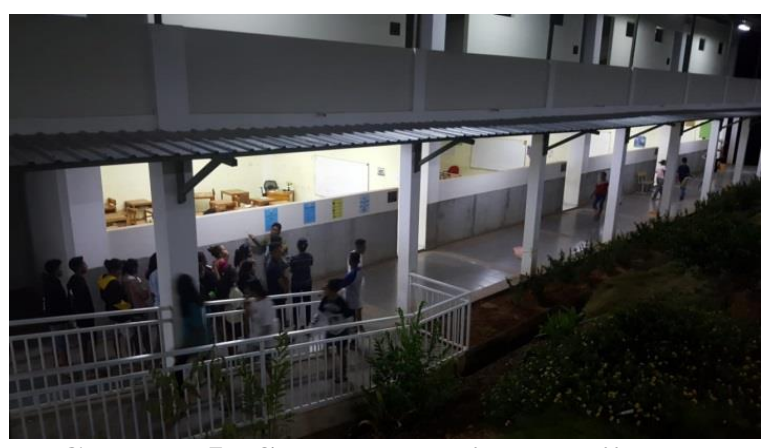

Gambar 5 - Suasana persiapan Ujian Nasional pada malam hari

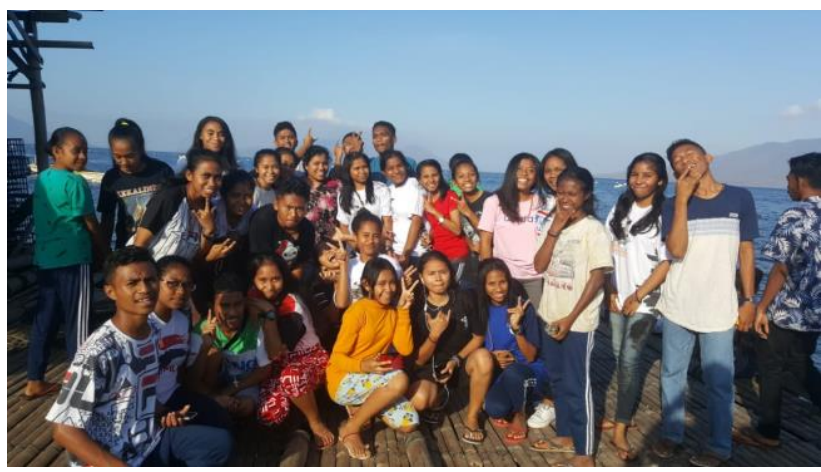

Gambar 6 - Keceriaan setiap sore setelah selesai sekolah alam

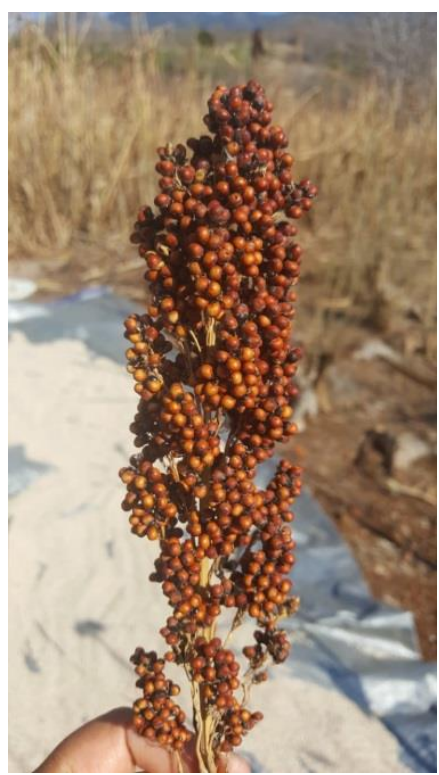

Gambar 7 - Sorgum sebagai komoditi utama di desa Likotuden

Pendidikan 727 


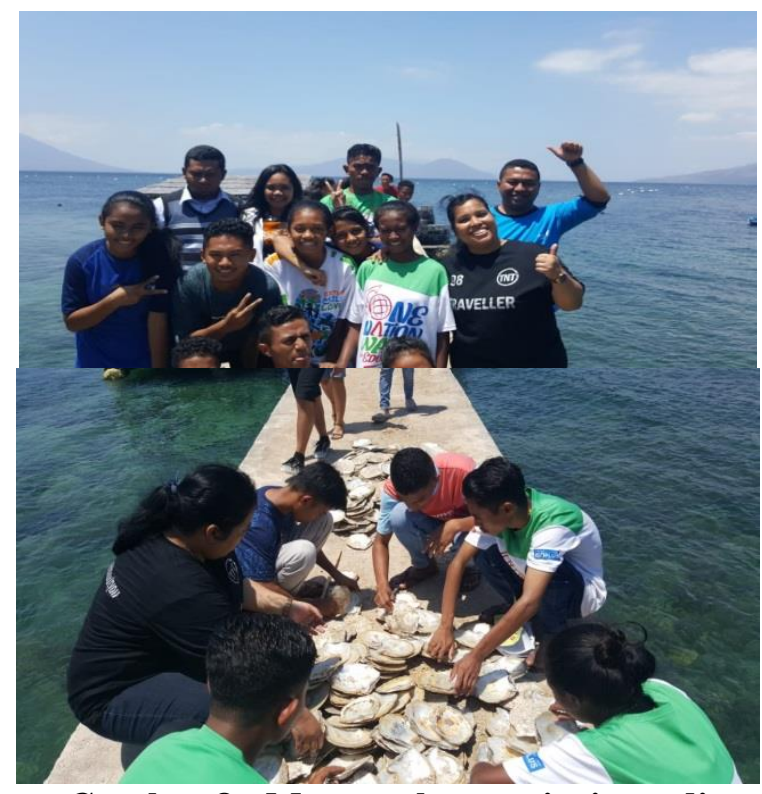

Gambar 8 - Mengenal potensi wisata di sekitar sekolah SMK Ancop Desa Likotuden

\section{SIMPULAN}

1. Guru dan siswa memiliki kesepakatan pengunaan sikap dasar pelayanan dalam kebiasaan sehari-hari di sekolah. Hal ini sebagai latihan dan membiasakan sikap pelayanan yang akan diterapkan di industri baik pada saat PRAKERIN maupun pada saat mereka bekerja setelah lulus.

2. Siswa/siswi SMK Ancop kelas XI merasa lebih siap dan percaya diri mengikuti PRAKERIN di travel agent. Setelah mereka mengikuti kegiatan walaupun dengan menggunakan fasilitas yang cukup terbatas serta mendapatkan suasana belajar di luar kelas, mereka lebih memahami pentingnya peranan Travel Agent dalam bisnis pariwisata serta alur bisnis serta produk jasa wisata yang dapat dijual. Selain itu kegiatan ini menumbuhkan motivasi mereka setelah mereka akan menyelesaikan sekolah di SMK Ancop dan tertarik akan bekerja di bidang pariwisata khususnya Travel Agent.

3. Jalan-jalan di sekitar sekolah berhasil mengajak siswa/siswi lebih mengenal potensi atraksi wisata yang dianggap biasa saja bagi mereka ternyata bisa sangat menarik bagi wisatawan. Potensi ini juga disadari dapat dikemas dalam paket wisata sebagai produk wisata Flores umumnya dan Larantuka pada khususnya yang dapat diperkenalkan kepada wisatawan.

4. Peserta juga merasa puas dan terbekali bagaimana penggunaan teknology berupa GDS yang dapat secara langsung dipraktikkan dengan bimbingan dan materi yang dibuat lebih mudah dimengerti dan menyenangkan dengan langsung menggunakan sistem Tiketing Domestik dan International, sehingga peserta merasa lebih percaya diri

5. Siswa siswi kelas XII sangat merasa lebih percaya diri untuk menghadapi ujian mata pelajaran Dokumen Pasasi International setelah secara bersama membedah dan menganalisa formula Mileage System yang pada awalnya membingungkan bagi mereka

6. Guru-guru yang mendampingi penulis selama memberikan pelatihan merasa lebih percaya diri untuk mengajar dikelas setelah mengikuti pelatihan bersama siswa siswi mereka dan banyak berdiskusi dan berbagi tips dengan penulis mengenai mata pelajaran vokasi di SMK Ancop

7. Keluaran dari mengikuti pelatihan ini adalah, diharapkan siswa setelah lulus dapat mengaplikasikan dan dapat membangun desanya dengan memetakan potensi wisata di desa mereka dan membuat paket wisata yang dapat ditawarkan kepada wisatawan. Selain itu, dapat menumbuhkan percaya diri menjadi entrepreneur muda di bidang pariwisata di Flores Timur.

8. Setelah melakukan pengambdian masyarakat di SMK Ancop penulis mengharapkan agar Yayasan lebih banyak memberikan pelatihanpelatihan di bidang pariwisata khususnya Usaha Perjalanan Wisata dengan retooling guru di Travel Agent maupun Airlines serta pelatihan terkait lainnya. Bekerja sama dengan berbagai pihak dalam penguatan internet di desa Likotuden dianggap penting, dikarenakan pentingnya mendapatkan informasi dan penggunaan berbagai aplikasi dan system untuk pembelajaran siswa 
maupun guru. Kelengkapan buku-buku maupun ebook pariwisata baik itu hospitality, pariwisata, Bisnis Travel sangat penting untuk kelengkapan perpustakaan sebagai media pembelajaran.

\section{REFERENSI}

Detiknews (2020) Tinjau Kelimutu, MPR minta ada SMK Pariwisata di Flores. Diakses 20 Juli 2020, dari https://news.detik.com/berita/d-5114430/tinjaukelimutu-mpr-minta-ada-smk-pariwisata-di$\underline{\text { Flores }}$

Frost, W., (2004) Travel \& Tour Management., Pearson Education., Australia

IATA, Ticketing Handbook, Diakses 10 Agustus $2020 \quad, \quad$ dari https://www.iata.org/en/publications/store/ticketi ng-handbook/
Info Publik (2017), Kemenpar : Peran SMK Pariwisata Dalam Pengembangan Digital Pariwisata Penting, Diakses 20 Juli 2017, dari http://infopublik.id/read/211907/kemenparperan-smk-pariwisata-dalam-pengembangandigital-tourism-penting.html

Lioe, L.S., Situmorang, R., Guna, A. (2019), Workshop Pengayaan Materi Praktik Kerja Industri Bagi Siswa SMK ANCOP Desa Kewalelo Flores Timur dari https://prosidingpkmcsr.org/index.php/pkmcsr/article/view/575

Martin, WB., (2002) Quality Service What Evey Hospitality Manager Needs to Know, Pearson Education., New Jersey 